\section{Ortho-nitrophenyl Complexes of Gold(III)}

J. VICENTE*, M. T. CHICOTE, A. ARCAS and M. ARTIGAO

Departamento de Química Inorgánica, Facultad de Ciencias, Universidad de Murcia, Spain

Received May 18, 1982

\section{Introduction}

Many organogold complexes have been prepared using Grignard or organolithium reagents [1], as well as organothallium [2] or organotin [3] complexes. We have recently shown that organomercury compounds can also be used for the synthesis of organogold(III) complexes which are inaccessible through other routes [4]. Many authors have used organomercurials in order to prepare organometallic compounds of other elements [5] and also of gold(I) [6]. We therefore thought it of interest to know how useful could organomercurials be in the synthesis of gold(III) complexes.

To test the method we chose a group such as ortho-nitrophenyl, which is difficult to bond to a metallic atom due to the unstability of the corresponding organolithium derivative [7] that has only scarcely been used [8]. The interest of preparing nitrophenyl organometallics is well documented, and the methods used are good examples of how the difficulties in the synthesis of organometallics can be overcome by choosing the proper intermediates [9-22]. In any case, this is the first report of the use of organomercurials in the synthesis of nitrophenyl complexes.

On the other hand it is known that ortho substituents exert a profound influence on the stability of arylmetal complexes [23-31] and this fact explains the great number of such complexes and the advances in the organometallic chemistry of many elements promoted by such special stability.

Our continuing interest in the synthesis of metallacycle complexes $[3,4,32]$ relates to the possibility of the ortho-nitrophenyl group acting as a new type of chelate ligand to give a fivemembered ring metallacycle. Although there is no evidence of such type of coordination in the complexes reported here, we have prepared some palladium(II) complexes where the metallacycle is present [33]. In the light of these results we conti-

\footnotetext{
*Author to whom correspondence should be addressed.
}

nue in our attempts to obtain similar findings in the chemistry of gold(III).

\section{Results and Discussion}

The reactions between $\left[\mathrm{HgR}_{2}\right]$ and $\mathrm{Me}_{4} \mathrm{~N}$. [AuCl $\left.{ }_{4}\right]$ give, after stirring for respectively 30 or $65 \mathrm{hr}$ in refluxing acetone, the anionic complexes $\mathrm{Me}_{4} \mathrm{~N}\left[\mathrm{AuR}_{2} \mathrm{Cl}_{2}\right]\left(\mathrm{R}=0-\mathrm{O}_{2} \mathrm{NC}_{6} \mathrm{H}_{4}(\mathrm{I}), 2-\mathrm{H}_{3} \mathrm{C}\right.$, 6- $\mathrm{O}_{2} \mathrm{NC}_{6} \mathrm{H}_{3}$ (II). The reaction with $\left[\mathrm{Hg}\left(\mathrm{C}_{6} \mathrm{H}_{5}\right)_{2}\right]$ in the same conditions gives metallic gold.

$$
\begin{aligned}
\mathrm{Me}_{4} \mathrm{~N}\left[\mathrm{AuCl}_{4}\right]+2\left[\mathrm{HgR}_{2}\right] & \rightarrow \\
& \mathrm{Me}_{4} \mathrm{~N}\left[\mathrm{AuR}_{2} \mathrm{Cl}_{2}\right]+2[\mathrm{HgRCl}]
\end{aligned}
$$

The 1.r. spectra of the complexes show two strong bands at $280,300 \mathrm{~cm}^{-1}$ (I) and 285,305 $\mathrm{cm}^{-1}$ (II) which can be assigned to $v(\mathrm{AuCl})\left(\mathrm{A}_{1}\right)$ and $\nu(\mathrm{AuCl})\left(\mathrm{B}_{1}\right)$ for a cis-geometry $\left(\mathrm{C}_{2 \mathrm{v}}\right)$. A transgeometry $\left(D_{2 b}\right)$ would give just a band $\left(B_{2 u}\right)$ in the region $340-360 \mathrm{~cm}^{-1}$ due to the lower trans. influence of chloro with respect to the phenyl group $[2 b, 34,35]$.

The cis-organometallic gold(III) complexes reported $\left[\mathrm{Au}\left(\mathrm{CH}_{3}\right)_{2} \mathrm{Cl}_{2}\right]^{-}[36]\left[\mathrm{Au}\left(\mathrm{C}_{6} \mathrm{~F}_{5}\right)_{2} \mathrm{Cl}_{2}\right]^{-},\left[\mathrm{Au}\left(\mathrm{C}_{6}-\right.\right.$ $\left.\left.\mathrm{F}_{3} \mathrm{H}_{2}\right)_{2} \mathrm{Cl}_{2}\right]^{-}$[2b] and $\left[\mathrm{Au}\left(2,2^{\prime}-\mathrm{C}_{12} \mathrm{H}_{8}\right) \mathrm{Cl}_{2}\right]^{-}$[3] also show two bands in their i.r. spectra at 268, 281; 310,$330 ; 315,320$ and $272,316 \mathrm{~cm}^{-1}$ respectively.

${ }^{1} \mathrm{H}$ n.m.r. of complex (II) shows a multiplet centered at 7.18 p.p.m. (6H, phenyl protons) and two singlets at 3.09 p.p.m. $\left(12 \mathrm{H}, \mathrm{N}\left(\mathrm{CH}_{3}\right)_{4}\right)$ and 2.52 p.p.m. $\left(6 \mathrm{H}, \mathrm{H}_{3} \mathrm{C}-\mathrm{Ph}\right)$.

When suspensions of complexes (I) or (II) in dichloromethane are treated with $\mathrm{PPh}_{3}(1: 1)$, suspensions of $\mathrm{Me}_{4} \mathrm{NCl}$ and solutions containing [ $\mathrm{Au}\left(o^{-}\right.$ $\left.\left.\mathrm{O}_{2} \mathrm{NC}_{6} \mathrm{H}_{4}\right)_{2} \mathrm{Cl}\left(\mathrm{PPh}_{3}\right)\right]$ (III) or [ $\mathrm{Au}\left(2 \cdot \mathrm{H}_{3} \mathrm{C}, 6-\mathrm{O}_{2} \mathrm{NC}_{6}\right.$. $\left.\left.\mathrm{H}_{3}\right)_{2} \mathrm{Cl}\left(\mathrm{PPh}_{3}\right)\right]$ (IV) are obtained.

$$
\begin{aligned}
\mathrm{Me}_{4} \mathrm{~N}\left[\mathrm{AuR}_{2} \mathrm{Cl}_{2}\right]+\mathrm{PPh}_{3} \rightarrow & \\
& {\left[\mathrm{AuR}_{2} \mathrm{Cl}\left(\mathrm{PPh}_{3}\right)\right]+\mathrm{Me}_{4} \mathrm{NCl} }
\end{aligned}
$$$$
\mathrm{R}=0 \cdot \mathrm{O}_{2} \mathrm{NC}_{6} \mathrm{H}_{4}(\mathrm{III}), 2-\mathrm{H}_{3} \mathrm{C}, 6-\mathrm{O}_{2} \mathrm{NC}_{6} \mathrm{H}_{3}
$$

When pyridine is used complex (I) reacts simlarly to give the complex $\left[\mathrm{Au}\left(o-\mathrm{O}_{2} \mathrm{NC}_{6} \mathrm{H}_{4}\right)_{2} \mathrm{Cl}(\mathrm{py})\right](\mathrm{V})$, but even if an excess of the ligand is used a mixture of (I) and (V) is always isolated, which can be separated due to the better solubility of $(V)$ in diethyl ether.

The three neutral complexes present a medium band at 320 (III), 310 (IV) and 315 (V) $\mathrm{cm}^{-}$. If complexes (III) - (V) were of trans-geometry we should expect in (V) $v(\mathrm{AuCl})$ trans to pyridine at 
higher frequency than $\nu(\mathrm{AuCl})$ trans to phosphine in (III) duc to the lower trans-influence of the pyr1dine ligand. In addition $\nu(\mathrm{AuCl})$ trans to pyridine has been assigned at $363 \mathrm{~cm}^{-1}$ in $\left[\mathrm{Au}(\mathrm{CN})_{2} \mathrm{Cl}(\mathrm{py})\right]$ [37].

For these reasons we assign the bands observed in the $310-320 \mathrm{~cm}^{-1}$ region to $\nu(\mathrm{AuCl})$ trans to the phenyl rings and then a cis-geometry for complexes (III)-(V).

In fact, complex (IV) shows in its ${ }^{1} \mathrm{H} n$ m.r. spectra a multiplet centered at 762 p p.m. $(21 \mathrm{H}$, phenyl rings) and two singlets at $2.69(3 \mathrm{H})$ and 2.18 p.p.m. (3H) corresponding to the two different $o$-methyl groups.

All complexes are thermally stable in the solud state and in solution, as well as towards atmospheric moisture and daylight.

\section{Experimental}

cis- $\mathrm{Me}_{4} \mathrm{~N}\left[\mathrm{Au}\left(\mathrm{o}-\mathrm{O}_{2} \mathrm{NC}_{6} \mathrm{H}_{4}\right)_{2} \mathrm{Cl}_{2}\right](I)$

To a solution of $\mathrm{Me}_{4} \mathrm{~N}$ [AuCl $\mathrm{Au}_{4}$ (139 mg, 0.34 mmol) in acetone $(40 \mathrm{ml}) \quad\left[\mathrm{Hg}\left(o-\mathrm{O}_{2} \mathrm{NC}_{6} \mathrm{H}_{4}\right)_{2}\right]$ [17] $(310 \mathrm{mg}, 07 \mathrm{mmol})$ was added and the mixture refluxed for $30 \mathrm{~h}$. Concentration of the solution (to $5 \mathrm{ml}$ ) and slow addition of diethyl ether $(30 \mathrm{ml})$ gave (I) (184 $\mathrm{mg}, 92 \%$ y1eld) as a pale yellow solid. $\mathrm{M}$ p. $186{ }^{\circ} \mathrm{C}, \Lambda_{\mathrm{M}}=115 \Omega^{-1} \mathrm{~cm}^{2} \mathrm{~mol}^{-1}$ (3.41 $\times 10^{-4} M$ in acetone solution). Analytical data. \% Found: $\mathrm{C}$ 32.82, $\mathrm{H}: 3.50, \mathrm{~N}$ 7.00, $\mathrm{Au} \cdot 33.30$. $\mathrm{C}_{16} \mathrm{H}_{20} \mathrm{~N}_{3} \mathrm{Cl}_{2} \mathrm{O}_{4} \mathrm{Au}$ requires $\mathrm{C} \cdot 32.78, \mathrm{H}: 3.44$, N. 7.17, $\mathrm{Au} 33.60$.

c1s- $\left.\mathrm{Me}_{4} \mathrm{~N} / \mathrm{Au}\left(2-\mathrm{H}_{3} \mathrm{C}, 6-\mathrm{O}_{2} \mathrm{NC}_{6} \mathrm{H}_{3}\right)_{2} \mathrm{Cl}_{2}\right]$ (II)

A solution of $\mathrm{Me}_{4} \mathrm{~N}\left[\mathrm{AuCl}_{4}\right](234 \mathrm{mg}, 057 \mathrm{mmol})$ and $\left[\mathrm{Hg}\left(2-\mathrm{H}_{3} \mathrm{C}, \quad 6-\mathrm{O}_{2} \mathrm{NC}_{6} \mathrm{H}_{3}\right)_{2}\right] \quad(533 \mathrm{mg}, 1.13$ $\mathrm{mmol})$ in acetone $(50 \mathrm{ml})$ was refluxed for $65 \mathrm{~h}$, filtered and concentrated until a white solid appeared [(I) + unreacted mercurial], which was filtered. To the solution diethyl ether was added and the precipitated solid filtered and washed with methanol and diethyl ether to give (II) $(295 \mathrm{mg}, 42 \%$ yield) as a white sold. M.p. $200 \mathrm{C}(\mathrm{d}) . \Lambda_{\mathrm{M}}=108 \Omega^{-1} \mathrm{~cm}^{2}$ $\mathrm{mol}^{-1}\left(5.0 \times 10^{-4} M\right.$ solution in acetone). Analytical data: \% Found $\mathrm{C}$ 34.74, H. 404, N: 6.86, $\mathrm{Au} \cdot 31.40 . \mathrm{C}_{18} \mathrm{H}_{24} \mathrm{~N}_{3} \mathrm{Cl}_{2} \mathrm{O}_{4} \mathrm{Au}$ requires: C 35.20, $\mathrm{H} \cdot 3.94, \mathrm{~N}: 6.84, \mathrm{Au} \cdot 3206$.

\section{c1s- $\left[\mathrm{Au}\left(\mathrm{o}-\mathrm{O}_{2} \mathrm{NC}_{6} \mathrm{H}_{4}\right)_{2} \mathrm{Cl}\left(\mathrm{PPh}_{3}\right)\right]$ (III)}

To a suspension of (I) $(60 \mathrm{mg}, 0.1 \mathrm{mmol})$ in dichloromethane $(20 \mathrm{ml})$ solid $\mathrm{PPh}_{3}(27 \mathrm{mg}, 0.1$ $\mathrm{mmol}$ ) was added. After stırring at room temperature for $5 \mathrm{~h}$ the suspension was filtered, the solution concentrated (to $2 \mathrm{ml}$ ) and n-hexane added to precipitate (III) $(64 \mathrm{mg}, 85 \%$ yreld) as a pale yellow solid. M.p. $151^{\circ}$ C. $\Lambda_{\mathrm{M}}=19.5 \Omega^{-1} \mathrm{~cm}^{2} \mathrm{~mol}^{-1}(3.8$ $\times 10^{-4} M$ solution in acetone). Analytical data.
\% Found. C: 47.92, H. 3.92, N. 3.79, Au. 25.76. $\mathrm{C}_{30} \mathrm{H}_{23} \mathrm{~N}_{2} \mathrm{ClO}_{4}$ PAu requires. C $4876, \mathrm{H} \cdot 3.14, \mathrm{~N}$ $3.79, \mathrm{Au} \cdot 26.66$.

CIs- $\left[\mathrm{Au}\left(2-\mathrm{H}_{3} \mathrm{C}, 6-\mathrm{O}_{2} \mathrm{NC}_{6} \mathrm{H}_{3}\right)_{2} \mathrm{Cl}\left(\mathrm{PPh}_{3}\right)\right](\mathrm{IV})$

To a suspension of (II) $(171 \mathrm{mg}, 0.28 \mathrm{mmol})$ in dichloromethane (10 mil) solid $\mathrm{PPh}_{3}(118 \mathrm{mg}, 0.45$ $\mathrm{mmol}$ ) was added. After stırning at room temperature for $1 \mathrm{~h}$ the suspension was filtered, the solution concentrated (to $2 \mathrm{ml}$ ) and dethyl ether added to precipitate (IV) (165 mg, 77\% yield) as a pale yellow solid. M p. $165^{\circ} \mathrm{C}$ (d). $\Lambda_{\mathrm{M}}=0.7 \Omega^{-1} \mathrm{~cm}^{2} \mathrm{~mol}^{-1}(1.4 \times$ $10^{-4} M$ solution in acetone) Analytical data: $\%$ Found: C. 50.22. H: 3.74, N 356, Au. 2517. $\mathrm{C}_{32} \mathrm{H}_{27} \mathrm{~N}_{2} \mathrm{ClO}_{4} \mathrm{PAu}$ requires C. $50.11 ; \mathrm{H}: 3.55$, $\mathrm{N}: 3.65$, Au. 25.68.

\section{cls- $\left[\mathrm{Au}\left(\mathrm{o}-\mathrm{O}_{2} \mathrm{NC}_{6} \mathrm{H}_{2}\right)_{2} \mathrm{Cl}(\mathrm{py})\right](\mathrm{V})$}

To a suspension of (I) $(100 \mathrm{mg}, 0.17 \mathrm{mmol})$ in dichloromethane $(25 \mathrm{ml})$ anhydrous pyridine $(0.5$ $\mathrm{ml}$ ) was added and the resulting suspension stirred for $12 \mathrm{~h}$ at room temperature and then filtered. The solution was concentrated (to $3 \mathrm{ml}$ ) and diethyl ether $(25 \mathrm{ml})$ added to give unreacted (I) and a solution that was concentrated (to $5 \mathrm{ml}$ ) and $\mathrm{n}$-hexane added $(25 \mathrm{ml})$ to precipitate $(\mathrm{V})(36 \mathrm{mg}, 38 \%$ yield $)$ as a clear yellow solid. M.p. $120^{\circ} \mathrm{C}(\mathrm{d}) . \Lambda_{\mathrm{M}}=15 \Omega^{-1}$ $\mathrm{cm}^{2} \mathrm{~mol}^{-1}\left(3.7 \times 10^{-4} M\right.$ solution in acetone $)$ Analytical data. \% Found C $3684, \mathrm{II} \cdot 3.09, \mathrm{~N}$ 7.73, $\mathrm{Au}$ 35.01. $\mathrm{C}_{17} \mathrm{H}_{13} \mathrm{~N}_{3} \mathrm{ClO}_{4} \mathrm{Au}$ requires $\mathrm{C}$ $36.74, \mathrm{H}: 2.36$, N. $7.56, \mathrm{Au} .35 .44$

\section{References}

1 R. J. Puddephatt, in R. J. H Clark (Ed.), 'The Chemistry of Gold', Elsevier, Amsterdam, 1978.

2 a) R.S. Nyholm and P. Royo, $J$ Chem. Soc, Chem Comm., 421 (1969),

b) R. Uson, A. Laguna, J. Garcia and M. Laguna, Inorg. Chtm. Acta, 37, 201 (1979) and references therein

3 R. Uson, J. Vicente, J. A Cirac and M T Chicote, $J$ Organometal Chem , 198, 105 (1980),

R. Uson, J Vicente and M. T. Chicote, J Organometal Chem., 209, 271 (1981)

$4 \mathrm{~J}$ Vicente and M. T Chicote, Inorg Chim Acta, 54, L259 (1981),

J. Vicente, M. T. Chicote and M. D. Bermudez, Inorg. Chim Acta, in press.

5 L G Makarova, Organometallic Reactrons, 1, 119 (1970) and refs. therein;

R. J Cross and R. Wardle, $J$ Chem. Soc, A, 840 (1970). V. I Sokolov, V V. Bashilov, L M Anishchenko and O. A Reutov, J. Organometal Chem, 71, C41(1974), W. A. Herrmann, Angew Chem. Int Ed, 13, 812 (1974); V I Sokolov, W. Bashilov and O A. Reutov, $J$ Organometal. Chem., 111, C13 (1976);

A. Segnitz, E. Kelly, S H. Taylor and P. M. Matlss, $J$. Organometal. Chem., 124, 113 (1977),

V. I Sokolov and O. A Reutov, Coord Chem. Rev, 27,89 (1978),

A. N. Nesmeyanov and A. Z. Rubezhov, J. Organometal Chem., 164, 259 (1979), 
R. J. Cross and N. H. Tennent, J. Organometal Chem., 72, $21(1974)$;

V. I. Sokolov, L. L. Troitskaya and O. A. Reutov, J Organometal. Chem., 93, C11 (1975);

R. E. Cobbledick, F. W. B. Eustein, W. R. McWhunie and I. H Musa, J. Chem Res., (S), 140, (M), 1901 (1979).

A. F. M. J. van der Ploeg, G. van Koten and K. Vrieze, J. Organometal. Chem., 222, 155 (1981).

J. L. Brianso, X. Solans and J. Vicente, J Chem Soc Dalton, in press.

6 P. W. J. de Graaf, A. J. de Koning, J. Boersma and G. J. M. van der Kerk, J. Organometal. Chem., 141, 345 (1977),

A. N. Nesmeyanov, E. G. Perevalova, M V Ovchinnikov, Yu. Ya. Sankin adn K. I. Grandberg, Izv Akad. Nauk., SSSR, Ser. Khtm, 1925 (1978).

7 P. Buck and G. Koebrich, Chem. Ber, 103, 1412 (1970).

8 P. Wiriyachita, J. J. Falcone and M. P. Cava, J. Org. Chem., 44, 3957 (1979)

9 R. A. Benkeser and P. E. Brunfield, J Am. Chem. Soc., 73,4770 (1951)

10 J. L. Speir, J. Am Chem. Soc., 75, 2930 (1953).

11 F. B. Deans and C. Eaborn, J. Chem. Soc, 498 (1957).

12 D. Azarian, S. S. Dua, C. Eaborn and D. R. M. Walton, J. Organometal. Chem., 117, C55 (1976).

13 H. Matsumoto, K. Yoshihiro, S. Nagashima, H. Watanabe and $Y$ Nagai, J Organometal. Chem., 128, 409 (1977).

14 H. Matsumoto, K. Shono and Y. Nagai, J Organometal. Chem., 208, 145 (1981).

15 D. Wrobel and V. Wannagat, J. Organometal Chem., 225, 203 (1982).

16 O. Dimroth, Ber., 35, 2032 (1902).

17 A. N. Nesmeyanov, N. F. Glushney, P. F. Epifanskiı and A. M. Flegontov, Ber., 67, 130 (1934).

18 F. Hein and K. Wagler, Ber., 58, 1499 (1925).
19 G. Sachs and K. Furst, Mh Chem, 53.54, 550 (1929).

20 F. F. Said and D. G. Tuck, $J$ Organometal. Chem., 224, 121 (1982)

21 P. Braunstcin, J. Chem. Soc. Chem. Comm., 851 (1973),

P. Braunste1n and R. J. H. Clark, Inorg Chem., 13, 2224 (1974).

22 P. W. J. de Graaf, J. Boersma and G. J. M. van der Kerk, J. Organometal. Chem., 105, 399 (1976).

23 J. Chatt and B. L. Shaw, J. Chem Soc., 1718 (1960).

24 G. J. Stolze, J. Organometal. Chem., 6, 383 (1966)

25 G. J. Stolze and J Hahle, J. Organometal Chem., 7, 301 (1967).

26 W. Seidel and G. Kreisel, Z. Chem., 14, 25 (1974).

27 W. Seldel and I. Burger, J. Organometal Chem., 117, C19 (1979).

28 J. K. Kochi, 'Organometallic Mechanisms and Catalysis', Academic Press, New York, 1978.

29 T. T. Tsou and J. K. Koch1, J. Am. Chem. Soc, 101, 6319 (1979).

30 J. C. Huffman, W. A Nugent and J. K Koch1, Inorg Chem., 19, 2749 (1980).

31 R. Uson, A. Laguna and J. Vicente, Syn React. Inorg Met-Org Chem., 7, 463 (1977).

32 R. Usón, J. Vicente and M. T. Chicote, Inorg Chim. Acta, 35, L305 (1979)

33 J. Vicente, M. T Chicote and M. Artigao, to be published.

34 L H. Jones, Inorg. Chem., 4, 1472 (1965).

$35 \mathrm{R}$ Uson, A. Laguna and J. Vicente, Rev. Acad. Clencias, Zaragoza, 31, 211 (1976).

36 W. M. Scovell and R. S. Tobias, Inorg Chem., 9, 945 (1970).

37 T. Bosch1, B. Crocian1, L. Cattalıni and G. Marangonı, $J$ Chem Soc. A, 2408 (1970). 